\title{
Absorption Pollutants Carbon Monoxide (CO) in the Air Using Sansevieria and Scindapsus Aureus
}

\author{
Anisa Furtakhul Janah ${ }^{1}$, Sulhadi ${ }^{2}$, Teguh Darsono ${ }^{2}$ \\ \{furtakhuljanah.anisa@gmail.com, sulhadipati@mail.unnes.ac.id, teguhfisikaunnes@mail.ac.id\} \\ SMK 17 Agustus 1945 Semarang, Jalan Kimangunsarkoro 16, Karangkidul, Semarang, Central Java, \\ Indonesia $^{1}$ \\ Graduate School, Universitas Negeri Semarang, Jalan Kelud Utara III, Gajahmungkur, Semarang, \\ Central Java, Indonesia ${ }^{2}$
}

\begin{abstract}
We often find the use of the insect repellent in everyday life. However, insect repellent is very harmful to health. The use of decorative plants are considered to be able to mitigate the negative effects of the insect repellent. This study aims to determine the ability of plants to absorb CO. In this study, the Sansevieria and Scindapsus Aureus plants were used as the media to reduce the concentration of CO. The data were analyzed quantitatively and qualitatively. The quantitative data were obtained from the calculation of the absorbed concentration using AAS (Atomic Absorption Spectrophotometer) test. The results showed that in the bright room, Sansevieria was able to absorb $\mathrm{CO}$ at: $0.06 \mathrm{ppm}$ $\left(25^{\circ} \mathrm{C}\right) ; 0.09 \mathrm{ppm}\left(30^{\circ} \mathrm{C}\right) ; 0.012 \mathrm{ppm}\left(35^{\circ} \mathrm{C}\right)$, and Scindapsus Aureus at $0.07 \mathrm{ppm}\left(25^{\circ} \mathrm{C}\right)$; $0.11 \mathrm{ppm}\left(30^{\circ} \mathrm{C}\right) ; 0.14 \mathrm{ppm}\left(35^{\circ} \mathrm{C}\right)$. Then, in a dark room Sansevieria was able to absorb $\mathrm{CO}$ at: $0.04 \mathrm{ppm}\left(25^{\circ} \mathrm{C}\right) ; 0.06 \mathrm{ppm}\left(30^{\circ} \mathrm{C}\right) ; 0.09 \mathrm{ppm}\left(35^{\circ} \mathrm{C}\right)$, and Scindapsus Aureus at $0.04 \mathrm{ppm}\left(25^{\circ} \mathrm{C}\right) ; 0.06 \mathrm{ppm}\left(30^{\circ} \mathrm{C}\right) ; 0.08 \mathrm{ppm}\left(35^{\circ} \mathrm{C}\right)$. Based on the results, Sansevieria and Scindapsus Aureus plants more effectively absorb the $\mathrm{CO}$ gas when it is placed in a bright room.
\end{abstract}

Keywords: Medication Mosquito, Sansevieria, Scindapsus Aureus, Carbon Monoxide, AAS.

\section{Introduction}

Air pollution not only occurs in outdoors, but also indoors, for instance, the effect of the use of odor, microorganisms, smoke, and insect repellent [1]. Data of ISPU (air pollution index), states that it belongs to quite good air category if the air quality does not give effect to human health and has no effect on plants and the aesthetic value of the building. Meanwhile, it is unhealthy air, if the air quality in a city generally can cause serious health problems to the local population [2].

In everyday life, particularly in a rural environment predominantly belong to the lower economic level, many still use insect repellent to protect against mosquitoes. An insect repellent contains more than 4000 kinds of chemical substances, and $15 \%$ of them are poisonous. The most dangerous chemicals are carbon monoxide $(\mathrm{CO})$. More carbon monoxide $(\mathrm{CO})$ in the free air will be oxidized to carbon dioxide $\left(\mathrm{CO}_{2}\right)$ [3]. Carbon monoxide $(\mathrm{CO})$ is a gaseous compound that is colorless and odorless.

Snake plant (Sansevieria) and Ivory Box (Scindapsus Aureus) is one of the ornamental plants that are often placed in offices, hotels, and homes as it can neutralize pollution [4]. 
Research conducted by the United States Space Agency (NASA) has found evidence that these plants are naturally able to combat Sick Building Syndrome, which is one of the phenomena of health problems related to indoor air quality [5]. Sansevieria and Scindapsus Aureus are able to produce fresh air in a room because the plants can absorb harmful substances in the air constantly [6][8].

Sanseviera and Scindapsus Aureus are classified as plants that are resistant to pollutants, so called as anti-pollutant plants. Sanseviera and Scindapsus Aureus plants are able to absorb carbon dioxide, carbon monoxide, benzene, formaldehyde, and tri-chloro ethylene. This study aims to determine the ability of Sanseviera and Scindapsus Aureus plants to absorb carbon monoxide $(\mathrm{CO})$ at temperatures and light categories for different rooms. The use of insect repellent in the house continuously can harm the body health, so we need a way to reduce the threat of air pollution in the house. Based on the description above, it is necessary to conduct a study on "Absorption of carbon monoxide $(\mathrm{CO})$ pollutants produced from insect repellent when used indoors by Sansievera and Scindapsus Aureus plants".

\section{Methods}

This research belongs to a descriptive exploratory study which used snakes plant (Sansevieria) and betel ivory (Scindapsus Aureus) as the samples. The data were collected both quantitatively and qualitatively. The quantitative data were obtained by the calculation of the concentration of carbon monoxide (CO) which can be absorbed by the leaves of Sansevieria and Scindapsus Aureus using AAS test (Atomic Absorption Spectrophotometer), while the qualitative data were described through quantitative data collection.

The equipment and materials used in this study included: (1) Sansevieria plant, (2) Scindapsus Aureus plant, (3) insect repellent, (4) a solution of nitric acid and perchloric acid, (5) room with the size of $4 \times 3 \times 4 \mathrm{~m}$, and (6) thermometer. The study would require variables to clarify the implementation of a study. The variables used in this study are divided into two, namely the dependent variable and independent variables. The dependent variable in this study included: (1) the contact time during the 7 days, (2) the time of exposure for 1 hour/day, (3) insect repellent which branded Kingkong, (4) the growing media: pot diameter of $8 \mathrm{~cm}$ filled the land.

The independent variables used in this study included: (1) the temperature of the water for watering plants: $25^{\circ} \mathrm{C}, 30^{\circ} \mathrm{C}$, and $35^{\circ} \mathrm{C}$, (2) types of plants: Sansevieria and Scindapsus Aureus, (3) the category of light to the room: dark and bright. Once the tools and materials are prepared, then do the appropriate research steps that have already been designed. Good research needs to pay attention to several things, including researching a systematic, clear and structured. The steps to do this research can be seen in Figure 1. 


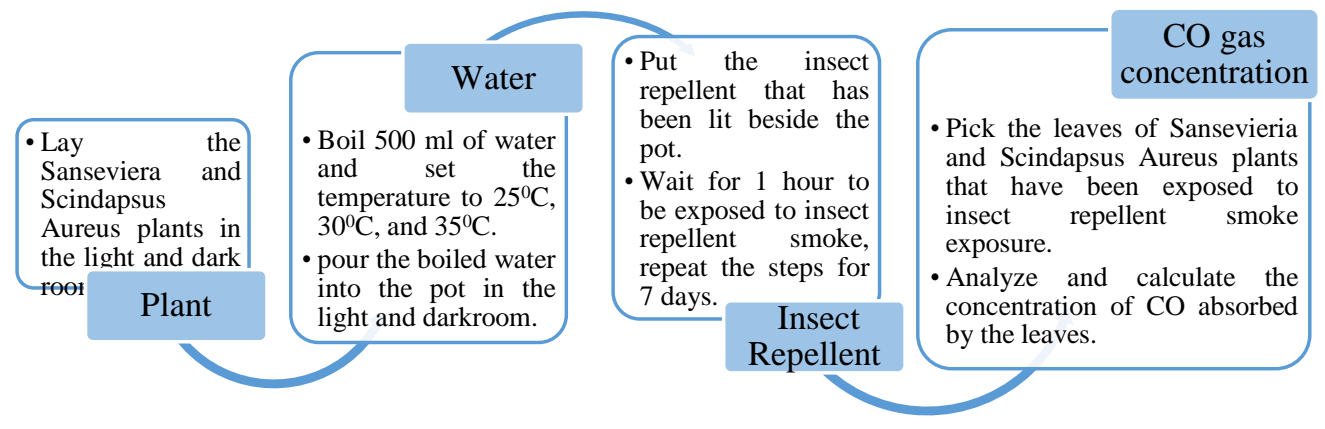

Figure 1. Research Prosedure

\section{Result and Discussion}

Based on the test results of AAS (Atomic Absorption Spectrophotometer), the concentration of carbon monoxide (CO) which can be absorbed by the leaves of Sansevieria presented in Table 1.

Table 1.The Ability of Sansevieria Plants in Absorbing Carbon Monoxide Gas

\begin{tabular}{cccc}
\hline \multirow{2}{*}{ Categories Lighting Room } & \multicolumn{4}{c}{ Water temperature for Plant Nutrition } \\
\cline { 2 - 4 } & $25^{\circ} \mathrm{C}$ & $30^{\circ} \mathrm{C}$ & $35^{\circ} \mathrm{C}$ \\
\hline Bright & 0.06 & 0.09 & 0.12 \\
Dark & 0.04 & 0.06 & 0.09 \\
\hline
\end{tabular}

Based on Table 1 it can be seen that there was a difference in concentrations of the gas absorption of carbon monoxide (CO) when placed in a dark room between in light room and varied in water temperature. In this study, the water used as a nutrient for Sansevieria and Scindapsus Aureus plants. The observation was done during the 7 days, and the presentation was performed every 1 hour/day. Based on the results of AAS test, when Sansevieria plant was placed in a bright room, the concentration of $\mathrm{CO}$ that can be absorbed by the leaves of Sansevieria when the plant is poured with the $25^{\circ}$ of water was $0.06 \mathrm{ppm}$. Then, when the Sansevieria plant doused with $30^{\circ} \mathrm{C}$ of water, the concentration of $\mathrm{CO}$ was $0.09 \mathrm{ppm}$. Furthermore, when the plants were poured with the $35^{\circ} \mathrm{C}$ of water, the concentration of $\mathrm{CO}$ that could be absorbed was $0.12 \mathrm{ppm}$.

Sansevieria plant placed in the darkroom was also tested and analyzed, based on test results, the concentration of CO that can be absorbed by the leaves of Sansevieria when doused with the $25^{\circ} \mathrm{C}$ of water was $0.04 \mathrm{ppm}$. Then, when the Sansevieria plant doused with the $30^{\circ} \mathrm{C}$ of water, the $\mathrm{CO}$ concentration was $0.06 \mathrm{ppm}$. Furthermore, when the plants were poured with the $35^{\circ} \mathrm{C}$ of water, the concentration of $\mathrm{CO}$ that could be absorbed was $0.09 \mathrm{ppm}$.

Based on AAS test results, the increasing the temperature of the water used for watering the Sansevieria plant, the more the carbon monoxide gas that can be absorbed. Form those three kinds of temperature, the temperature of $35^{\circ} \mathrm{C}$ produced the greatest concentration of carbon monoxide absorption rate. 
Besides, there were differences between the concentration of $\mathrm{CO}$ absorbed by plants of Sansevieria when placed in a bright and in darkroom. Sansevieria plants placed in the bright room absorbed more carbon monoxide gas, due to when the plants were in a bright room got adequate light to assist the process of growth. Thus, it was quite effective that Sansevieria plant absorbed carbon monoxide gas in the air.

Furthermore, to determine the concentration of carbon monoxide $(\mathrm{CO})$ absorbed by the leaves of Scindapsus Aureus can be seen in Table 2.

Table 2.The ability of Scindapsus Aureus Plant in Absorbing Carbon Monoxide Gas

\begin{tabular}{cccc}
\hline \multirow{2}{*}{ Categories Lighting Room } & \multicolumn{3}{c}{ Water temperature for Plant Nutrition } \\
\cline { 2 - 4 } & $25^{\circ} \mathrm{C}$ & $30^{\circ} \mathrm{C}$ & $35^{\circ} \mathrm{C}$ \\
\hline Bright & 0.07 & 0.11 & 0.14 \\
Dark & 0.04 & 0.06 & 0.08 \\
\hline
\end{tabular}

Table 2 explains the difference in the concentration of carbon monoxide (CO) when placed in a bright room and in dark room. This study did variations on the temperature of water used as plant nutrients Scindapsus Aureus, The observation was done during 7 days, and presented every 1 hour/day. Based on the results of AAS test, Scindapsus Aureus plant when placed in a bright room, the concentration of $\mathrm{CO}$ absorbed by the leaves of Scindapsus Aureus when the plant was poured with $25^{\circ} \mathrm{C}$ of water was $0.07 \mathrm{ppm}$. Then, when the Scindapsus Aureus plant doused with $30^{\circ} \mathrm{C}$ of water, the concentration of absorbed $\mathrm{CO}$ was $0.11 \mathrm{ppm}$. Furthermore, when the plants were poured with the $35^{\circ} \mathrm{C}$ of water, the concentration of absorbed $\mathrm{CO}$ was $0.14 \mathrm{ppm}$.

Furthermore, the Scindapsus Aureus plant placed in the darkroom was also tested and analyzed. Based on AAS test results, the concentration of $\mathrm{CO}$ that can be absorbed by the leaves of Scindapsus Aureus when the plant was poured with $25^{\circ} \mathrm{C}$ of water was $0.04 \mathrm{ppm}$. Then, when the plant of Scindapsus Aureus doused with the $30^{\circ} \mathrm{C}$ of water, the concentration of $\mathrm{CO}$ was $0.06 \mathrm{ppm}$. Furthermore, the Scindapsus Aureus plant poured with $35^{\circ} \mathrm{C}$ of water, the absorbed CO concentration was $0.08 \mathrm{ppm}$.

Based on AAS test results, the increasing the temperature of the water used for watering the Scindapsus Aureus plant, the more carbon monoxide gas that can be absorbed. From those three inds of temperature, the temperature of $35^{\circ} \mathrm{C}$ was greatest concentration of carbon monoxide absorption rate. Besides, when the Scindapsus Aureus plant placed in a bright room absorbed more carbon monoxide gas compared with the plants placed in a dark room.

From the test results of Sansevieria AAS in plants and Scindapsus Aureus, we can conlclude that the two plants mentioned were quite effectively used to reduce air pollution in the houses. It was due to the ability of plants to absorb carbon monoxide gas produced from the smoke of insect repellent. The ability of Sansevieria and Scindapsus Aureusin plants to absorb carbon monoxide gas can be seen in Figure 2. 


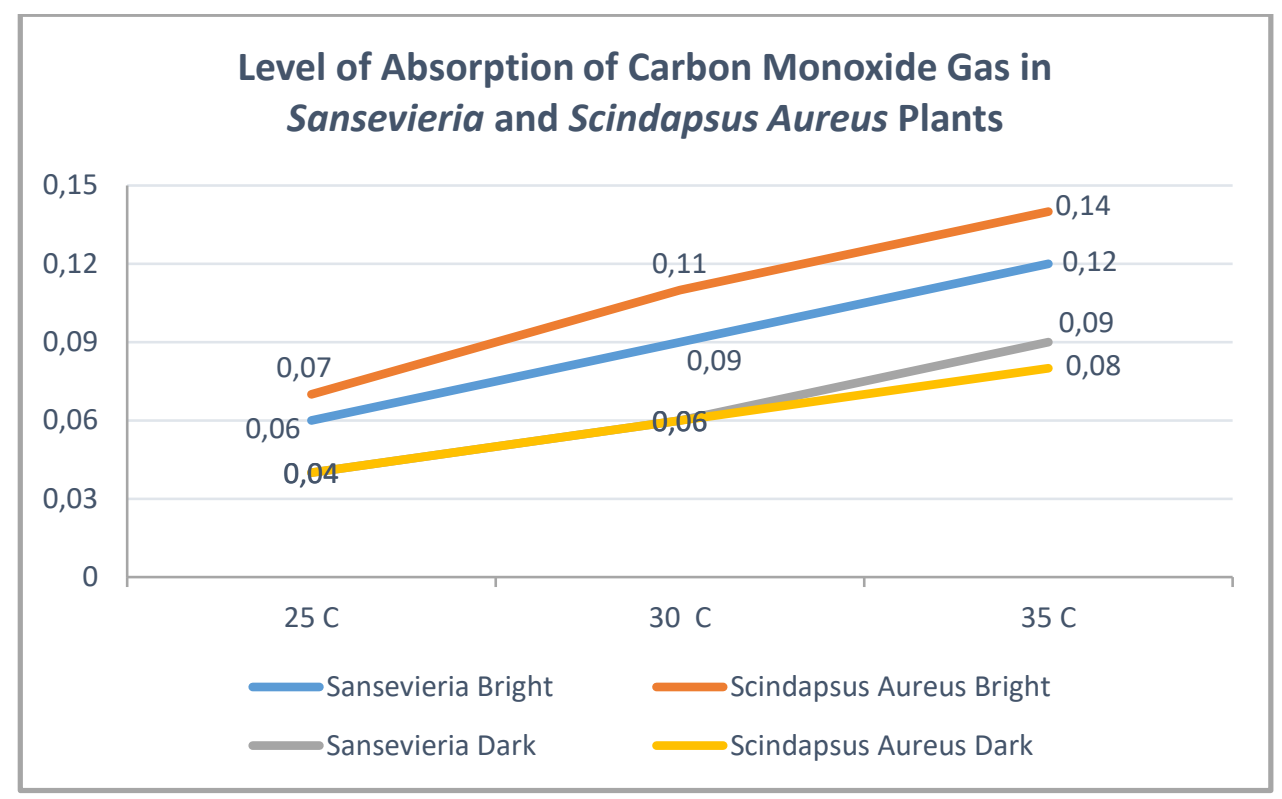

Figure. 2. Absorption Levels of CO gas in Sansevieria and Scindapsus Aureus Plants

Based on Figure 2, the Scindapsus Aureus plant absorbed more carbon monoxide (CO) when compared with the Sansevieria plant when placed in a bright room. That was due to Scindapsus Aureus plant got adequate light to maintain the growth and development of plants. Plant growth and development were influenced by many factors, one of them was the plant nutrient should obtain adequate and good lighting.

\section{Conclusion}

Based on the results of research and discussion, it can be concluded that the higher the temperature of the water used for watering plants, the higher the ability of plants to absorb carbon monoxide (CO) in the air. Besides, the plants which placed in the bright room absorb more $\mathrm{CO}$ gas, due to the plant has adequate nutrition for growth and development. From this research, the Scindapsus Aureus plants absorb more CO gas when compared with the Sansevieria plant. Both plants absorb most of the $\mathrm{CO}$ gas when doused with water in the temperature of $35^{\circ} \mathrm{C}$. 


\section{References}

[1] Nugrahani, P. \& Sukartiningrum.: Air Pollution Tolerance Index (APTI) Median garden plants Jalan Surabaya. Mapeta Agricultural Journal, Vol. 10,pp. 86-92 (2008)

[2] Afif, B.: Air Pollution: Air Pollution Impacts the Environment. News Aerospace, Vol. 2, (2001)

[3] Aditia, C., Ratni J.A. \& Naniek, R.: The level of absorption capability in the Ornamental Plant Pollutant Reduces Carbon Monoxide. Scientific Journal of Environmental Engineering, Vol. 4, (2011) [4] Siti, N. \& Iffah, B.: Effects of Media Growth and Fertilization on Growth Through Ornamental Leaves dieffenbachia Picta Inside and Outside the room. Agronomy Journal, Vol. 12,pp. 11-13 (1981) [5] Sugiarti.: Gas Pollutant And Influence For Human Health. Chemica Journal, Vol. 10,pp. 50-58 (2009)

[6] Bovi, R. \& Naniek, R.: The rate of absorption ability of Ornamental Plants on Reducing Pollutants Carbon Monoxide. Scientific Journal of Environmental Engineering, Vol. 4, (2012)

[7] Ebadi, A.G., Zare,S., Mahdavi, M. \& Babaee, M.: Study and Measurement of Pb, Cd, Cr and Zn in Green Leaf Of Tea Cultivated in Gillan Province of Iran. Pakistan Journal of Nutrition, Vol. 4,pp. 270272 (2005)

[8] Karliansyah, N.W.: Chlorophyll Leaf Mahogany as a Bioindicator Angsana and Air Pollution. Environment and Development Journal, Vol. 19,pp. 290-305 (1999) 